\title{
Mekanisme Pasar Dalam Perspektif Ekonomi Islam
}

\author{
Yenni Samri Juliati Nasution ${ }^{1}$ \\ Fakultas Ekonomi Dan Bisnis Islam UIN-SU Medan \\ hajjahyen@gmail.com
}

\begin{abstract}
The market is a mechanism for the exchange of goods and services that nature. The market price is formed by a variety of factors which later formed the demand and supply of goods and services. Consumer demand is influenced by many factors, such as price, consumer income, tastes, expectations and level mashlahah. Quote manufacturers also influenced by many factors, such as mashlahah, profits, and prices. Interaction of supply and demand will establish the balance point can be changed from the demand side or the supply, either due to the deviation of structured and unstructured deviation. Perfectly competitive market can generate a fair price for the seller and the buyer. Therefore, if the market mechanism is interrupted, then the fair price will not be achieved. Islam puts the market at an important position in the economy. And very concerned about the concept of a fair price and perfect market mechanism. So, the role of government is very important to better ensure the activities of market mechanisms as perfect as taking a policy of price intervention that is based on justice.
\end{abstract}

Keywords: Market, mechanisms, Islamic, economics.

\begin{abstract}
Pasar adalah sebuah mekanisme untuk pertukaran barang dan jasa yang sifatnya alami. Harga pasar dibentuk oleh berbagai faktor yang kemudian membentuk permintaan dan penawaran barang dan jasa. Permintaan konsumen dipengaruhi oleh banyak faktor, seperti harga, pendapatan konsumen, selera, harapan dan tingkat mashlahah. Sedangkan penawaran produsen juga dipengaruhi oleh banyak faktor, seperti mashlahah, laba, dan harga. Interaksi antara penawaran dan permintaan yang akan membentuk titik keseimbangan dapat diubah dari sisi permintaan atau penawaran, baik sebagai akibat dari deviasi terstruktur maupun deviasi yang tidak terstruktur. Pasar persaingan sempurna akan dapat menghasilkan harga yang adil bagi penjual dan pembeli. Oleh karena itu, jika mekanisme pasar terganggu, maka keadilan harga tidak akan bisa tercapai. Islam menempatkan pasar pada posisi yang penting dalam ekonomi. Dan juga Islam sangat memperhatikan dengan konsep harga yang adil dan mekanisme pasar yang sempurna. Maka peranan pemerintah sangat penting untuk lebih menjamin aktivitas mekanisme pasar secara sempurna seperti mengambil kebijakan intervensi harga yang tetap berpijak kepada keadilan.
\end{abstract}

Kata kunci: Mekanisme, pasar, Islam, ekonomi. 


\section{Pendahuluan}

Pasar adalah bertemunya permintaan dan penawaran atas satu macam barang/ jasa. Dipasar antara para pembeli dan penjual saling tawar menawar untuk menentukan harga berbagai jenis barang. Dalam analisis ekonomi, pengertian pasar tidak terbatas kepada suatu tempat tertentu tetapi meliputi suatu daerah, negara dan bahkan dunia internasional. Pasar untuk karet dan timah, misalnya, bukanlah dimaksudkan sebagai tempat jual beli karet atau timah di suatu kampung atau wilayah tertentu tetapi meliputi interaksi di antara produsenprodusen dan pembeli karet atau timah di seluruh pelosok dunia.

Pasar dimana para pembeli dan para penjual melakukan interaksi dapat dibedakan dalam dua jenis: Pasar barang dan pasar faktor. Pasar barang adalah tempat dimana para pembeli dan para penjual dari suatu barang atau jasa melakukan interaksi untuk menentukan jumlah dan harga barang atau jasa yang diperjualbelikan. Sedangan pasar faktor adalah tempat di mana para pengusaha (pembeli faktor-faktor prosuksi) mengadakan interaksi dengan pemilik-pemilik faktor produksi untuk menentukan harga (pendapatan) dan jumlah faktor-faktor produksi yang akan digunakan dalam menghasilkan barang-barang dan jasa-jasa yang diminta masyarakat.

Mekanisme pasar dapat mengalokasikan faktor-faktor produksi dengan cukup efisien dan dapat mendorong perkembangan ekonomi disebabkan karena ia memiliki beberapa kebaikan. Kebaikan mekanisme pasar adalah: Pasar dapat memberi informasi yang lebih tepat, Pasar memberi memacu untuk mengembangkan kegiatan usaha, Pasar memberi mendorong untuk memperoleh keahlian Modern, Pasar menggalakkan penggunaan barang dan faktor produksi secara efisien, Pasar memberikan kebebasan yang tinggi kepada masyarakat untuk melakukan kegiatan ekonomi.

\section{Macam-Macam Pasar}

Dalam teori ekonomi banyak dikenal macam-macam pasar, baik yang pada praktiknya sering dilihat kenyataannya sehari-hari maupun yang hanya dikenal secara absolut dalam teori. Macam pasar yang umumnya banyak dipraktikkan biasanya adalah monopoli, monopolistis, dan oligopoli. Macam pasar yang secara absolut hanya ada dalam teori ekonomi adalah bentuk persaingan murni dan 
persaingan sempurna. Persaingan murni dan persaingan sempurna meskipun secara utuh tidak dapat dipraktikkan, tetapi pada praktiknya banyak juga terdapat dalam kenyataan sehari-hari, misalnya pasar pakaian di Pasar Atas Bukit Tinggi, Pasar tas dan sepatu di Tanggulangin Sidoarjo. Beberapa ciri dari persaingan murni dan sempurna yang banyak dipraktikkan sehari-hari diantaranya adalah barang yang diperjualbelikan sama, jumlah pembeli dan penjualnya banyak, serta mudah keluar dan masuk bagi pengusahaa. Secara garis besar, macam-macam pasar ditinjau dari segi penjual adalah sebagai berikut: ${ }^{2}$

1. Persaingan sempurna

2. Monopoli

3. Monopolistis

4. Oligopoli

Bila ditinjau dari sisi pembeli, macam-macam pasar dapat dibagi menjadi sebagai berikut:

1. Monopsoni

2. Oligopoli

3. Persaingan sempurna.

Pasar adalah bertemunya permintaan dan penawaran atas satu macam barang/ jasa. Yaitu posisi di mana terdapat sejumlah barang tertentu yang mau dan mampu dibeli oleh konsumen.

\section{Pasar Persaingan Sempurna}

Persaingan sempurna merupakan struktur pasar yang paling ideal, karena dianggap sistem pasar ini adalah struktur pasar yang akan menjamin terwujudnya kegiatan memproduksi barang atau jasa yang tinggi (optimal) efisiensinya. ${ }^{3}$ Pasar persaingan sempurna muncul karena adanya prinsip - prinsip sebagai berikut :

a. Tidak ada satu penjual tunggal yang mempunyai sumber cukup banyak untuk dapat mempengaruhi harganya di pasar

b. Sumber variabel mempunyai mobilitas yang tinggi untuk berbagai harga pasar dan penggunaannya relatif fleksibel.

Karena prinsip-prinsip tersebut di atas maka pada pasar persaingan sempurna akan dipenuhi dengan adanya syarat - syarat sebagai berikut : 
4 | At-Tawassuth, Vol. III, No. 1, 2018: 1 - 22

1. Jumlah produsen di mana volume produksi hanya bagian kecil dari total volume transaksi pasar, sehingga dengan kata lain secara individual tidak bisa mempengaruhi harga pasar atau baik produsen maupun konsumen bertindak sebagai Price Taker ( penerima harga ).

2. Produk homogen ( jenis maupun kualitas )

3. Setiap produsen maupun konsumen tahu informasi pasar ( simetris information )

4. Bentuk kurva permintaan horisontal, karena tidak terdapat perubahan harga berapapun jumlah barang yang akan diminta oleh konsumen atau ditawarkan oleh produsen

5. Untuk mencapai keuntungan maksimum pada suatu perusahaan adalah dengan melihat besar volume output yang dihasilkan.

Dalam persaingan sempurna terdapat 2 keseimbangan yaitu:

1. Keseimbangan produsen secara individual akan tercapai apabila keuntungan perusahaan maksimum

2. Ekuilibrium pasar apabila semua perusahaan dalam posisi equilibrium.

Pasar persaingan sempurna dibagi menjadi 2 yaitu:

1) Jangka pendek dengan asumsi setiap produsen tidak bisa menambah kapasistas produksinya dan tidak ada produsen baru keluar atau masuk kedalam pasar.

2) Jangka Panjang dengan asumsi dimungkinkan adanya perluasan kapasitas produksi.

Ciri-ciri dari pasar persaingan sempurna adalah: ${ }^{4}$ Perusahaan adalah pengambil harga, setiap perusahaan mudah keluar atau masuk, menghasilkan barang serupa, terdapat banyak Perusahaan di Pasar, pembeli mempunyai pengetahuan yang sempurna mengenai Pasar.

\section{Pasar Monopoli}


Monopoli secara harfiah berarti di pasar hanya ada satu penjual. ${ }^{5}$ Frank Fisher menjelaskan kekuatan monopoli sebagai " the ability to act in unconstrained way" ( kemampuan bertindak [dalam menentukan harga] dengan cara sendiri), sedangkan Besanko menjelaskan monopoli sebagai penjual yang menghadapi “ little or no competition (kecil atau tidak ada pesaing) di pasar.

Dalam Islam keberadaan satu penjual di pasar, atau tidak adanya pesaing, atau kecilnya persaingan pasar, bukanlah suatu hal yang terlarang. Siapapun boleh berdagang tanpa peduli apakah dia satu-satunya penjual atau ada penjual lain. Jadi monopoli dalam artian harfiah, boleh-boleh saja. Akan tetapi, siapapun dia tidak boleh melakukan ihtikar. Islam tidak membolehkan pembantukan atau penguasaan monopoli yang bersifat pribadi, yang kemungkinan merugikan bagi masyarakat. ${ }^{6}$ Ciri-ciri pasar monopoli:

1) Produsen sebagai 'Price Maker'

2) Permintaan pasar merupakan bentuk dari permintaan perusahaan

3) Marginal Revenue lebih rendah daripada averagenya

4) MR berslope negatif

Sebab-sebab terjadinya monopoli :

1) Penguasaan bahan mentah strategis = Absolut advantage.

2) Adanya hak paten = Competitive Advantage .

3) Terbatasnya pasar

4) Pemberian hak monopoli oleh pemerintah ${ }^{7}$

Apabila dalam jangka panjang ada keuntungan maka perusahaan akan menciptakan Barier to Entry atau hambatan bagi produsen lain untuk ikut masuk pada pasar. Macam-macam Barier to Entry:

1. Natural Barier, yaitu hambatannya tercipta secara alami

2. Minimum Efficiency to Scale, perusahaan tersebut secara alami karena lokasi, sumber daya, tehnologi memungkinkan perusahaan untuk berporduksi dengan biaya lebih murah. Dengan mengacu pada comparative advantage.

3. Set Up Cost. Perusahaan yang bersangkutan merupakan satu-satunya yang mampu membiayai seluruh kegiatan produksi yang tinggi.

Cara menghilangkan efek negatif dari Monopoli : 
6 | At-Tawassuth, Vol. III, No. 1, 2018: 1 - 22

a. Mencegah timbulnya monopoli

b. Pemerintah mendirikan perusahaan tandingan

c. Import barang

d. Dibuat peraturan khusus / Undang - Undang.

\section{Persaingan Monopolistik}

Pada pasar persaingan monopolistik terdapat adanya unsur kompetisi yang didasarkan kenyataan bahwa terdapat banyak perusahaan / produsen dimana tindakan satu produsen akan mempengaruhi produsen yang lain. Tetapi juga terdapat unsur monopoli di mana perusahaan memproduksi barang yang homogen tapi masing-masing mempunyai perbedaan yang signifikan sehingga konsumen punya pilihan.

Ciri-ciri Persaingan Monopolistik :

1. Terdapat banyak perusahaan dalam industri tersebut

2. Tindakan / keputusan yang diambil oleh suatu perusahaan akan mempengaruhi perusahaan yang lain.

3. Kurva permintaan perusahaan pesaing adalah berslope negatif dan cukup elastis

4. Meski jenis produknya sama tapi tidak homogen, terdapat perbedaan yang menyebabkan konsumen mempunyai pilihan

5. Persaingan yang dilakukan bukan dalam bentuk harga

6. Tidak terdapat rintangan untuk keluar masuk pasar

Pasar Monopolistik memiliki ciri-ciri: produknya homogen, Jumlah produsen sangat banyak dan pengaruh terhadap harga tidak ada Tidak perlu bersaing karena produsen tidak bisa mempengaruhi harga. Produknya sama tapi dibedakan dengan merk dan kemasan. Hanya sedikit produsen dan masingmasing berpengaruh atas segmen persaingan yang terjadi bukan bersifat harga, tapi cenderung iklan. Unsur terpenting dalam Pasar Persaingan Monopolistik adalah:

1. Produsen jumlahnya cukup banyak, dengan barang yang homogen tapi mempunyai diferensiasi produk. ${ }^{8}$ Diferensiasi ini yang akan diunggulkan oleh 
perusahaan untuk menarik pangsa pasar. Misalnya lokasi, fasilitas pembayaran, periklanan dan lain-lain, yang sifatnya bukan harga.

2. Rintangan masuk dalam pasar adalah karena faktor finansial.

3. Kecenderungan pasar persaingan monopolistik yang produsennya banyak menyebabkan tingkat kapasitas produksinya rendah / tidak bekerja dengan optimal sehingga untuk meraih keuntungan dengan menetapkan harga yang relatif tinggi. (Misalnya banyaknya apotik pada satu kota tertentu).

Karena itu maka perusahaan yang ada dalam pasar persaingan monopolistik banyak yang melakukan diferensiasi produk agar mampu bertahan dan memperoleh keuntungan dalam jangka panjang. Misalnya dengan penciptaan barang yang sama tapi dengan type, style, merk dan harga yang berbeda untuk menjangkau hampir semua pangsa pasar yang ada. (Misalnya Pasar Sabun: Lux, Giv, Lifebouy). Pasar Shampo (Clear, Sunsilk, Pantene dan lain-lain). Advertensi merupakan hal yang paling pokok dalam pasar persaingan monopolistik.

Advertensi dan promosi penjualan mencoba membujuk konsumen dengan mencocokkan permintaan dengan produk yang ditawarkan penjual sementara Diferensiasi Produk berusaha menggugah selera yang dimiliki konsumen dengan penganekaragaman jenis barang. Adapun tujuan iklan adalah :

a) Membedakan produk perusahaan dengan perusahaan lain untuk jenis barang yang sama dan menimbulkan kefanatikkan atau kesetiaan terhadap merk tertentu.

b) Membuat kurva menjadi kurang elastis (in elastis) atau semakin curam yang artinya perubahan terhadap harga tidak akan memberikan pengaruh yang terlalu besar terhadap permintaan akan barang.

\section{Kebaikan dan Keburukan Iklan}

Memberikan informasi yang membantu konsumen membuat pilihan yang rasional, juga informasi tentang produk baru dan perbaikan atas produk yang telah ada. Mendukung komunikasi, dimana sarana seperti radio, surat kabar, TV dan Media sosial merupakan tempat untuk berilan yang digunakan para produsen. Bila Iklan berhasil maka akan tercapai skala ekonomi, Pengeluaran konsumen secara agregat meningkat, kesempatan kerja naik dan pendapatan secara nasional juga 
akan bergerak naik. Mendorong perusahaan untuk selalu berinovasi agar tidak kalah dengan perusahaan pesaing. Tujuan yang terjadi justru masyarakat terbujuk mengikuti pola hidup konsumtif dan bersaing. Dan acapkali masyarakat sebagai konsumen bersedia membeli dengan harga lebih mahal karena pengaruh iklan.

Kegiatan iklan yang tidak produktif bahkan terjadi alokasi sumber yang tidak pada tempatnya, misalnya pengeluaran untuk iklan lebih besar dibanding ongkos priode. Punya biaya eksternal yang tinggi misalnya menimbulkan kegaduhan untuk mobil reklame, pemandangan yang kotor untuk spanduk dan lain-lain. Menaikkan biaya secara signifikan pada perusahaan dan akan menimbulkan monopoli karena perusahaan yang beriklan banyak (mempunyai dana yang besar) akan menjadi pemenang.

\section{Pasar Oligopoli}

Pasar Oligopoli menunjukkan adanya produsen yang jumlahnya terbatas/ sedikit dan jumlah konsumen yang sangat banyak. Terdapat 2 macam oligopoli yaitu :

a. Produknya homogen ( contohnya: baja, semen, pupuk dan lain-lain )

b. Terdapat diferensiasi Produk (contohnya: Otomotif, Handphone, laptop dan lain-lain).

Tindakan yang dilakukan oleh seorang produsen akan langsung ditanggapi oleh produsen yang lain.

Ciri - ciri pasar Oligopoli:

a. Terdapat beberapa orang produsen dengan konsumen yang relatif banyak. Tiap produsen mempunyai pengaruh atas harga.

b. Terdapat barier to entry bagi produsen lain sehingga jumlah perusahaan akan cenderung konstan.

c. Penguasaan pangsa pasar ditunjukkan dengan nisbah konsentrasi penjualan yang dihitung berdasarkan jumlah atau persentase aktiva perusahaan terhadap total aktiva pasar.

d. Perang harga merupakan unsur yang sangat dihindari karena akan menimbulkan kerusakan secara masal dalam pasar oligopoli. Untuk menghindarinya maka dilakukan kolusi antar perusahaan. Sehingga cenderung akan menciptakan kartel. ${ }^{9}$ 
e. Perusahaan yang tidak mampu bersaing akan cenderung melakukan merger dengan perusahaan yang kuat.

f. Inovasi dan penguasaan terhadap tehnologi merupakan unsur yang penting dalam kemajuan perusahaan.

Perbaikan kualitas produk akan memperluas pangsa dan menurunkan biaya produksi yang tidak akan bisa ditiru dengan cepat oleh pesaingnya. Banyaknya pesaing yang kuat akan memaksa perusahaan melakukan efisiensi dalam segi biaya secara maksimum. (Economic of scale) dengan comparative advantage.

\section{Distorsi Pasar Perpektif Islam}

Dalam konsep Islam, penentuan harga dilakukan oleh kekuatan-kekuatan pasar, yaitu kekuatan permintaan dan penawaran tersebut harus terjadi rela sama rela, tidak ada pihak yang merasa terpaksa atau tertipu dengan adanya kekeliruan objek transaksi dalam melakukan transaksi barang tertentu (Q) pada tingkat harga (P) tertentu. Islam menjamin pasar bebas dimana para pembeli dan para penjual bersaing satu sama lain dengan arus informasi yang berjalan lancar dalam kerangka keadilan, yakni tidak ada (baik individu maupun kelompok, produsen maupun konsumen, apalagi pemerintah) yang zalim atau dizalimi. Semua itu merupakan situasi ideal. Namun pada kenyataannya, situasi ideal tersebut tidak selalu tercapai, karena sering kali terjadi gangguan/interupsi pada mekanisme pasar yang ideal. Gangguan ini disebut dengan Distorsi Pasar (market distortion).

Pada garis besarnya, ekonomi Islam mengidentifikasi tiga bentuk distorsi pasar yaitu :

1. Rekayasa penawaran dan rekayasa permintaan

2. Tadlis (penipuan)

3. Taghrir (dari kata gharar $=$ uncertainty, kerancuan $)$.

Dalam Ekonomi Islam, rekayasa penawaran (false supply) lebih dikenal dengan ihtikar, sedangkan rekayasa permintaan (false demand) dikenal dengan bai' najasy.

Untuk Tadlis (penipuan = unknow to one party) terdapat 4 bentuk yaitu : 
10 | At-Tawassuth, Vol. III, No. 1, 2018: 1 - 22
a. Penipuan menyangkut jumlah barang (quantity)
b. Mutu barang (quality)
c. Harga barang (price)
d. Dan waktu penyerahan barang (time of delivery)

Sedangkan taghrir (kerancuan, ketidak pastian $=$ unknow to both parties) juga terdapat 4 bentuk yang menyangkut :
a. Kualitas
b. Kuantitas
c. Harga
d. Dan waktu penyerahan barang

\section{Ketidaksempurnaan bekerjanya pasar}

Ketidaksempurnaan pasar bisa terjadi disebabkan : ${ }^{10}$

1. Penyimpangan terstruktur

Sturktur atau bentuk organisasi pasar akan mengganggu mekanisme pasar dengan cara yang sistematis dan terstruktur pula. Struktur pasar yang dimaksudkan adalah monopoli, duopoli, oligopoli dan kompetisi monopolistik. Dalam monopoli misalnya, terdapat halangan untuk masuk (entry barrier) bagi pengusaha lain ynag ingin memasuki pasar sehingga tidak terdapat persaingan antarprodusen. Produsen monopolis dapat saja mematok harga tinggi untuk memperoleh keuntungan di atas normal (monopolistic rent). Demikian pula bentuk pasar lainnya, meskipun pengaruh distorsinya tidak sekuat monopoli, akan mendistorsi bekerjanya pasar yang sempurna.

2. Penyimpangan tidak terstruktur

Selain itu, terdapat juga faktor-faktor insidental dan temporer yang mengganggu mekanisme pasar. Beberapa contoh hal ini adalah usaha sengaja menimbun untuk menghambat pasokan barang agar harga pasar menjadi tinggi (ikhtikar), penciptaaan permintaan semu untuk menaikkan harga (najasyi), penipuan kuantitas, kualitas, harga, atau waktu pengiriman barang (tadlis), kolusi para pedangang untuk membuat harga diatas harga normal (Ba'i al-hadir lil badi) dan lain-lain. 
3. Ketidaksempurnaan informasi dan penyesuaian

Informasi merupakan hal penting karena merupakan dasar bagi pembuatan keputusan. Produsen berkepentingan untuk mengetahui seberapa besar permintaan pasar dan tingkat harganya, dan lain-lain sehingga dapat menawarkan barangnya secara akurat. Begitu juga dengan konsumen yang harus mengetahui tingkat harga pasar yang berlaku sehinnga dapat menentukan permintaannya dengan akurat pula. Rasulullah Saw. telah melarang ketidaksempurnaan informasi, misalnya menghalangi transaksi pada harga pasar (talaqi rukhban), mengambil keuntungan tinggi dengan memamfaatkan kebodohan konsumen (ghaban fa hisy), dan sebagainya.

\section{Solusi Islam Terhadap Ketidaksempurnaan Bekerjanya Pasar Larangan Ihktikar}

Rasulullah Saw. telah melarang praktik ikhtikar, yaitu secara sengaja menahan atau menimbun barang, terutama pada saat terjadi kelangkaan, dengan tujuan untuk menaikkan harga dikemudian hari. Dari Said bin al-Musyyab dan Ma'mar bin Abdullah al- Adawi bahwa Rasulullah Saw. bersabda: "Tidaklah orang melakukan ikhtikar itu melainkan berdosa" ." Rasulullah Saw. juga bersabda "Siapa yang merusak harga pasar hingga harga itu melonjak tajam, maka Allah akan menempatkannya di dalam neraka pada hari kiamat.” (HR. Thabrani).

Praktik ikhtikar akan menyebabkan mekanisme pasar terganggu, dimana produsen kemudian akan menjual dengan harga yang lebih tinggi dari harga normal. Penjual akan memperoleh untung yang besar sedang konsumen mengalami kerugian. Ihtikar sering kali diterjemahi sebagai monopoli dan/atau penimbunan. Padahal ihtikar tidak identik dengan monopoli dan/atau penimbunan, dalam Islam siapapun boleh berbisnis tanpa peduli apakah dia satu-satunya penjual (monopoli) atau ada penjual lain. Menyimpan stock barang untuk keperluan persediaan pun tidak dilarang dalam Islam. Jadi, monopoli sah-sah saja, demikian juga dengan menyimpan persediaan. Yang dilarang adalah ihtikar, yaitu mengambil keuntungan diatas keuntungan normal dengan cara menjual lebih sedikit barang untuk harga yang lebih tinggi, atau istilah ekonominya monopoly's 
rent-seeking. Jadi, dalam Islam monopoli boleh, sedangkan monopoly's rentseeking tidak boleh.

Agar harga kembali pada posisi yang harga pasar, maka Pemerintah melakukan berbagai upaya menghilangkan penimbunan ini. Apabila telah terjadi penimbunan barang, maka pemerintah berhak memaksa para pedagang untuk menjual barang tersebut dengan harga standar yang berlaku dipasar. Bahkan, menurut para ulama, barang yang ditimbun oleh para pedagang dijual dengan harga modalnya dan pedagang tersebut tidak dibenarkan mengambil keuntungan sebagai hukuman terhadap mereka. Sekiranya para pedagang itu enggan menjual barangnya dengan harga pasar, maka pihak penegak hukum (hakim) dapat menyita barang itu dan kemudian membagikannya kepada masyarakat yang memerlukannya.

Pihak pemerintah seharusnya setiap saat memantau dan mengantisipasi, agar tidak terjadi ikhtikar dalam setiap komoditas, manfaat dan jasa yang dapat diperlukan masyarakat. Harga standar yang tidak memberatkan masyarakat dan merugikan pedagang harus dipadukan, dan tidak sampai menguntungkan sepihak, masyarakat atau pedagang.

\section{Membuka akses informasi}

Beberapa larangan terhadap praktek penipuan (tadlis) pada dasarnya adalah upaya untuk menyebarkan keterbukaan informasi sehingga transaksi dapat dilakukan dengan sama-sama suka (antaradin minkum) dan adil.

Kondisi ideal dalam pasar adalah apabila penjual dan pembeli mempunyai informasi yang sama tentang barang yang dierjual belikan. Apabila slah satu pihak tidak mempunyai informasi seperti yang dimiliki oleh pihak lain, maka salah satu pihak akan merasa dirugikan dan terjadi kecurangan/penipuan.

Al-qur'an dengan tegas melarang semua transaksi bisnis yang mengandung unsur penipuan dalam segala bentuk terhadap pihak lain. Dalam surat Al-An'aam : 152 yang artinya : “Dan sempurnakanlah takaran dan timbangan dengan adil. Kami tidak memikul beban kepada seseorang, melainkan sekedar kesanggupannya." 
Dalam sistem ekonomi Islam, hal ini juga dilarang karena adanya informasi yang tidak sama antara kedua belah pihak, maka unsur "an Tarradin Minkum” (rela sama rela) dilanggar. Untuk menghindari penipuan, masingmasing pihak harus mempelajari strategi pihak lain. Berikut ini akan dipaparkan macam-macam Tadlis (penipuan) yang ada dalam transaksi ekonomi:

\section{a) Tadlis dalam Kuantitas}

Tadlis (penipuan) dalam kuantitas termasuk juga kegiatan menjual barang kuantitas sedikit dengan harga barang kuantitas banyak. Misalnya menjual baju sebanyak satu kontainer. Karena jumlahnya banyak dan tidak mungkin untuk menghitung satu per satu, penjual berusaha melakukan penipuan dengan mengurangi jumlah barang yang dikirim kepada pembeli.Perlakuan penjual untuk tidak jujur disamping merugikan pihak penjual juga merugikan pihak pembeli. Apa pun tindakan pembeli, penjual yang tidak jujur akan mengalami penurunan utility, begitu juga dengan pembeli yang mengalami penurunan utility. Praktik mengurangi timbangan dan mengurangi takaran merupakan contoh klasik yang selalu digunakan untuk menerangkan penipuan kuantitas ini. Oleh karena itu, Islam sejak 1300 tahun yang lalu telah melakukan langkah-langkah untuk membuat standarisasi timbangan sebagai alat ukur.

\section{b) Tadlis dalam Kualitas}

Tadlis (penipuan) dalam kualitas termasuk juga menyembunyikan cacat atau kualitas barang yang buruk yang tidak sesuai dengan yang disepakati oleh penjual dan pembeli. Keseimbangan pasar hanya akan terjadi bila harga yang tercipta merupakan konsekuensi dari kualitas dan kuantitas barang yang di transaksikan. Apabila tadlis kualitas terjadi, maka syarat untuk pencapaian keseimbangan tidak akan tercapai. Oleh karena itu, dalam pendekatan ilmu ekonomi pun hal ini tidak dibenarkan. Itulah sebabnya Rasulullah Saw. melarang pertukaran satu sak kurma kualitas baik dengan dua sak kurma kualitas buruk, "jual kurma kualitas buruk, dapatkan uang, beli kurma kualitas baik dengan uangmu." Kurma kualitas baik mempunyai pasarnya sendiri, kurma kualitas buruk juga mempunyai pasarnya sendiri. 


\section{c) Tadlis dalam Harga (Ghaban)}

Al-Ghaban menurut bahasa bermakna al-khada' (penipuan). Ghaban adalah membeli sesuatu dengan harga yang lebih tinggi dan harga rata-rata atau dengan harga rendah dari rata-rata. ${ }^{12}$ Tadlis (penipuan) dalam harga ini termasuk menjual barang dengan harga yang lebih tinggi atau lebih rendah dari harga pasar karena ketidaktahuan pembeli atau penjual. Dalam fiqih disebut juga dengan ghaban. Di zaman Rasulullah Saw, perdagangan seperti berikut juga dilarang. Seperti yang diriwayatkan oleh Abdullah Ibn Umar "Kami pernah keluar mencegat orangorang yang datang membawa hasil panen mereka dari luar kota, lalu kami membelinya dari mereka. Rasulullah Saw melarang kami membelinya sampai nanti barang tersebut dibawa kepasar."

\section{d) Tadlis dalam Waktu Penyerahan}

Seperti juga pada tadlis (penipuan) dalam kuantitas, kualitas, dan harga, tadlis dalam waktu penyerahan juga dilarang. Yang termasuk penipuan jenis ini adalah bila si penjual tahu persis ia tidak akan dapat menyerahkan barang pada esok hari, namun menjanjikan akan menyerahkan barang tersebut pada esok hari. Walau konsekuensi tadlis dalam waktu penyerahan tidak berkaitan secara dengan harga ataupun jumlah barang yang ditransaksikan, namun masalah waktu adalah sesuatu yang sanagat penting. Lebih lanjut pelarangan ini dapat kita hubungkan dengan larangan transaksi yang lain, yaitu transaksi kali bali. Dengan adanya pelarangan tadlis waktu penyerahan, maka segala transaksi harus jelas kapan pemindahan hak milik dan hak guna terjadi. Berbeda dengan transaksi kali bali (transaksi jual beli, dimana objek barang atau jasa yang diperjualbelikan belum berpindah kepemilikan, namun sudah diperjualbelikan kepada pihak lain) dimana transkasi juga dilarang oleh Rasulullah Saw, bersabda "Siapapun yang membeli gandum tidak berhak menjualnya sebelum memperoleh hak kepemilikan.” Mengapa transaksi tanpa ada pemindahan kepemindahan kepemilikan ini dilarang? Taus pernah juga menyakan hal ini kepada Ibnu Abbas tentang alasan Rasulullah melarang hal ini dan dijawabnya bahwa hal itu sama saja menjual uang untuk memperoleh uang karena tidak ada gandum yang akan dibayar pada waktu itu. 
Sesungguhnya transaksi kali bi kali bisa dilakukan karena pada transaksi yang barang yang sama ada peluang untuk memanfaatkan waktu penyerahan yang berbeda dengan transaksi sebelumnya. Karena waktu yang berbeda tersebutlah, biasanya transaksi kali bi kali sering diikuti oleh tadlis dalam waktu penyerahan. Talaqi rukhban, Membeli barang dengan cara mencegat penjual di luar kota pada dasarnya supaya para penjual bisa mengetahui situasi pasar dengan segala informasi yang ada termasuk harga pasar dan praktik yang terkait dengan itu. Bay najasyi yaitu mencakup pengertian kolusi dimana antar penjual satu dengan yang lain melakukan kerja sama untuk menipu konsumen. Ghaban faahisy merupakan upaya sengaja untuk mengaburkan informasi sebab penjual memanfaatkan ketidaktahuan konsumen untuk mencari keuntungan tinggi. Islam menganggap penipuan dan kecurangan terhadap takaran,timbangan, atau kualitas barang sebagai perbuatan dosa. Allah Swt. berfirman “ celakalah bagi orang - orang yang mengurangi takaran,dengan cara apabila mereka membeli mereka minta di lebihkan, dan apabila mereka menimbang untuk orang lain, maka mereka kurangi. Tidakkah mereka menyangka bahwa mereka akan dibangkitkan (setelah mati )".

\section{Transaksi -transaksi yang dilarang dalam Ekonomi Islam}

\section{1) Bai’ Najasy}

Transaksi najasy diharamkan karena sipenjual menyuruh sesorang untuk memuji barangnya atau menawarnya dengan harga tinggi agar orang lain tertarik untuk membeli. Sipenawar sendiri tidak bermaksud untuk benar-benar ingin membeli barang tersebut. Ia hanya ingin menipu orang lain yang ingin membeli , sebelumnya orang ini telah mengadakan kesepakatan dengan penjual untuk membeli dengan harga tinggi agar ada pembeli yang sesungguhnya dengan harga yang tinggi pula dengan maksud untuk ditipu. Akibatnya terjadi "permintaan palsu" (false demand). Tingkat permintaannya yang tercipta tidak dihasilkan secara alamiah.

\section{2) Tallaqi Rukban}

Masih dalam menjelaskan distorsi pasar pada sisi penawaran, tindakan yang dilakukan oleh pedagang kota (pihak yang lebih memiliki informasi yang lebih lengkap) membeli barang petani (produsen yang tidak memiliki informasi 
yang benar tentang harga di pasar) yang masih diluar kota, untuk mendapatkan harga yang lebih murah dari harga pasar yang sesungguhnya. Rasulullah melarang hal ini, yang ada dalam fiqih disebut tallaqi rukban. Transaksi ini dilarang karena mengandung dua hal yaitu :

1. Mencegah masuknya barang ke pasar (entry barrier)

2. Mencegah penjual dari luar kota untuk mengetahui harga pasar yang berlaku.

Inti dari pelarangan ini adalah tidak adilnya tindakan yang dilakukan oleh pedagang kota yang tidak menginformasikan harga yang sesungguhnya terjadi di pasar. Mencari barang dengan harga yang lebih murah tidaklah dilarang, namun apabila transaksi jual beli antara dua pihak dimana yang satu memiliki informasi yang lengkap dan yang satu tidak tidak tahu berapa harga di pasar yang sesungguhnya dan kondisi demikian dimanfaatkan untuk mencari keuntungan yang lebih, maka terjadilah penzaliman antara pedagang kota dengan petani diluar kota tersebut maka hal ini dilarang.

Abu Hurairah pernah meriwayatkan, bahwa Rasulullah Saw, bersabda : "Janganlah kau keluar menyambut orang-orang yang bawa hasil panen ke dalam kota kita." Hikmah yang bisa diambil dari pelarangan ini adalah pembelian hasil panen yang merupakan komoditi yang pokok dan dibutuhkan semua orang, baik kaya maupun miskin harus dijual secara terbuka dipasar. Hal ini untuk mencegah pembelian tunggal komoditi pokok tersebut kepada satu pihak, dengan demikian pemerintah lebih midah untuk mengontrol harga di pasar.

\section{Taghrir (Uncertain To Both Parties)}

Taghrir berasal dari kata Bahasa Arab gharar, yang berarti : akibat, bencana, bahaya, resiko, dan ketidak pastian. Dalam istilah fiqih mu'amalah taghrir berarti melakukan sesuatu secara membabi buta tanpa pengetahuan yang mencukupi; atau mengambil risiko sendiri dari suatu perbuatan yang mengandung resiko tanpa mengetahui dengan persis apa akibatnya, atau memasuki kancah resiko tanpa memikirkan konsekuensinya.

Taghrir maupun tadlis keduanya terjadi karena adanya incomeplete information, namun,berbeda dengan tadlis, dimana incomplete information ini hanya dialami oleh satu pihak saja (unknow to one party, misalnya pembeli saja, 
atau penjual saja), dalam taghrir, incomplete information ini dialami oleh kedua belah pihak (baik pembeli maupun penjual). Karena itu, kasus taghrir terjadi bila ada unsur ketidakpastian yang melibatkan kedua belah pihak (uncertain to both parties).

Dalam ilmu Ekonomi Islam, taghrir ini lebih dikenal dengan uncertainty (ketidak pastian) atau resiko. Macam-macam Taghrir :

\section{a. Taghrir dalam Kuantitas}

Contoh taghrir dalam kuantitas adalah sistem ijon, misalnya petani sepakat untuk menjual hasil panennya (beras dengan kualitas A) kepada tengkulak dengan harga Rp. 2.000.000,00 pada hal pada saat kesepakatan dilakukan, sawah si petani belum dapat dipanen. Dengan demikian, kesepakatan jual beli dilakukan tanpa menyebutkan spesifikasi mengenai beberapa kuantitas yang dijual (berapa ton, berapa kuintal) padahal harga sudah ditetapkan. Dengan demikian, terjadi ketidakpastian menyangkut kuantitas barang yang ditransaksikan. Sesungguhnya Allah, hanya pada sisi-Nya saja penegetahuan tentang hari kiamat; dan Dia-lah Yang Menurunkan hujan, dan mengetahui apa yang ada dalam rahim. Dan tiada seorang-pun dapat mengetahui (dengan pasti) apa yang akan diusahakannya besok.......(QS Al-Luqman : 30).

Karena produsen menghadapi pasar persaingan sempurna maka keseimbangan akan tercipta ketika kurva permintaan $(\mathrm{D}=\mathrm{P}=\mathrm{MR}=\mathrm{AR})$ dengan kurva penawaran. Namun, yang menjadi permasalahan pada taghrir kuantitas disini adalah transaksi terjadi dengan harga yang sudah pasti untuk dipertukarkan dengan sejumlah barang yang belum pasti jumlahnya. Artinya kurva permintaan sudah jelas, namun kurva penawaran belum dapat ditentukan pada kurva yang mana penawaran yang sesungguhnya akan terjadi. Dengan demikian, pada taghrir kuantitas ini keseimbangan yang dicapai adalah keseimbangan yang semu dan tidak pasti.

\section{b. Taghrir dalam Kualitas}

Contoh taghrir dalam kualitas adalah menjual anak sapi yang masih dalam kandungan induknya. Penjual sepakat untuk menyerahkan anak sapi tersebut segera setelah anak sapi itu lahir, seharga Rp. 3.000.000,00. Dalam hal ini, baik fisik maupun si pembeli tidak dapat memastikan kondisi fisik anak sapi tersebut 
bila nanti sudah lahir. Apakah akan lahir normal, atau cacat, atau lahir dalam keadaan mati. Dengan demikian terjadi ketidakpastian menyangkut kualitas barang yang ditransaksikan.

\section{c. Taghrir dalam Harga}

Tagrir dalam harga terjadi ketika misalnya seorang penjual menyatakan bahwa ia akan menjual satu unit Sepeda Motor seharga Rp. 13.000.000 bila dibayar tunai, atau Rp. 21.000.000., bila dibayar kredit selama lima bulan, kemudian sipembeli menjawab "setuju”. Ketidak pastian muncul karena ada dua harga dalam satu akad. Tidak jelas harga mana yang berlaku, yang Rp. 13.000.000 atau yang Rp. 21.000.000. Dalam kasus ini walaupun kualitas dan kuantitas barang sudah ditentukan, tetapi terjadi ketidak pastian dalam harga barang karena si penjual dan si pembeli tidak mensepakati satu harga dalam satu akad.

\section{d. Tagrir Menyangkut Waktu Penyerahan}

Misalkan Sari kehilangan mobil Avanza-nya. Nurul kebetulan sudah lama ingin memiliki mobil Avanza seperti yang dimiliki oleh Sari, dan karena itu ia ingin membelinya. Akirnya Sari dan Nurul membuat kesepakatan. Sari menjual mobil Avanza-nya yang hilang denga harga Rp. 100 juta kepada Nurul. Harga pasar avanza adalah Rp. 170 juta. Mobil akan diserahkan segera setelah ditemukan. Dalam hal ini terjadi ketidak pastian menyangkut waktu penyerahan barang, karena barang yang dijual tidak diketahui keberadaannya. Mungin mobil tersebut tidak akan ditemukan sama sekali.

\section{Regulasi Harga}

Regulasi harga adalah pengaturan terhadap harga barang-barang yang dilakukan pemerintah. ${ }^{13}$ Dalam penetapan harga di pasar atas produksi , fakor yang sangat berpengaruh adalah permintaan dan penawaran.Regulasi harga ini merupakan hal yang tidak populer dalam khasanah pemikiran ekonomi Islam sebab harga yang tidak tepat justru dapat menciptakan ketidakadilan. Menurut Mannan, regulasi harga menunjukkan tiga fungsi dasar, yaitu :

1. Fungsi ekonomi yang berhubungan dengan peningkatan produktivitas dan peningkatan pendapatan masyarakat miskin melalui alokasi dan realokasi sumber daya ekonomi. 
2. Fungsi sosial dalam memelihara keseimbangan social antara masyarakat kaya dan miskin

3. Fungsi moral dalam menegakkan nilai- nilai syariah Islam, khususnya yang berkaitan dalam transaksi ekonomi.

Jika pasar telah bekerja dengan sempurna, maka tidak ada alasan untuk mengatur tingkat harga. Penetapan harga kemungkinan justru akan mendistorsi harga sehingga akhirnya mengganggu mekanisme pasar itu sendiri. Pada masa Rasulullah dan Umar bin Khattab, kota Madinah pernah mengalami kenaikan tingkat harga barang - barang karena menurunnya pasokan di pasar akibat gagal panen. Beliau menolak permintaan para sahabat untuk mengatur harga pasar, tetapi melakukan impor besar-besaran sejumlah barang dari Mesir, sehingga penawaran barang-barang di Madinah kembali melimpah dan tingkat harga mengalami penurunan.

Namun pada masa Umar bin khattab langkah ini tidak memadai. Tingkat daya beli masyarakat Madinah saat itu begitu rendah sehingga harga baru ini pun tidak terjangkau. Akhirnya Khalifah Umar mengeluarkan sejenis kupon yang dapat ditukarkan dengan sejumlah barang tertentu. Dengan melihat contoh ini, pada dasarnya jika Pemerintah ingin mempengaruhi harga pasar, maka dilakukan dengan cara memengaruhi permintaan dan penawaran.

Jumhur ulama sepakat bahwa kondisi darurat dapat menjadi alasan pemerintah mengambil kebijakan intervensi harga, tetapi tetap berpijak kepada keadilan. Maksudnya:

1. Harga naik diluar kewajaran sehingga tidak terjangkau masyarakat

2. Menyangkut barang-barang yang amat dibutuhkan oleh masyarakat, sedangkan penjual tidak mau menjualnya

3. Terjadi ketidakadilan antara pelaku transaksi tersebut.

Untuk lebih menjamin berjalannya mekanisme pasar secara sempurna peranan pemerintah sangat penting. Rasulullah telah menjalankan fungsi sebagai market supervisor atau Al-hisbah, yang kemudian banyak dijadikan acuan untuk peran Negara terhadap pasar. Menurut Al-Mawardi, eksistensi dan peranan al hisbah berangkat dari firman Allah " dan hendaklah di antara kamu ada 
segolongan umat yang menyuruh kepada kebaikan, menyuruh kepada yang ma'ruf dan mencegah dari yang munkar : merekalah orang-orang yang beruntung “. Sementara dalam bukunya Al-Hisbah Fi'l Islam, Ibnu Taimiyah ${ }^{14}$ banyak mengungkap tentang peranan Al-hisbah pada masa Rasulullah. Dimana Rasulullah Saw. sering melakukan inspeksi ke pasar untuk mengecek harga dan mekanisme pasar. Islam telah menggariskan sitem pengawasan yang dapat dicanangkan dalam rangka melanggengkan mekanisme dan struktur pasar. Sistem pengawasan pasar berlaku dalam sistem ganda dan berjenjang, yaitu: pengawasan pelaku pasar atas dirinya sendiri (internal) dan pengawasan yang dilakukan oleh pihak lain (eksternal). ${ }^{15}$

\section{Kesimpulan}

Konsep Islam menegaskan bahwa pasar harus berdiri di atas prinsip persaingan bebas (perfect competition), namun demikian bukan berarti kebebasan tersebut berlaku mutlak, akan tetapi kebebasan dengan frame aturan syariah. Dan konsep yang menentukan bahwa pasar islami harus bisa menjamin adanya kebebasan masuk atau keluarnya sebuah komoditas di pasar berikut perangkat faktor-faktor produksinya. Hal ini dimaksudkan untuk menjamin adanya pendistribusian kekuatan ekonomi dalam sebuah mekanisme yang proporsional. Agar pasar dapat berperan secara normal (alamiah) dan terjamin keberlangsungannya, dimana struktur dan mekanisme pasar dapat terhindar dari perilaku-perilaku negatif para pelaku pasar, maka ajaran islam juga menawarkan aturan moral berbasis syariah yang melindungi setiap kepentingan pelaku pasar.

Seluruh usaha negara untuk menjamin kesejahteraan, keadilan, dan aturan main yang adil dalam seluruh aktivitas kehidupan dicerminkan dalam institusi hisbah. Institusi hisbah tidak hanya memungkinkan pasar beroperasi dengan bebas dan membuat harga, keuntungan di tentukan oleh kekuatan supply dan demand, tetapi pada saat yang sama juga menjamin bahwa semua pranata ekonomi telah melaksanakan seluruh kewajibannya dan telah mematuhi aturan syariah. 


\section{Catatan}

${ }^{1}$ Penulis adalah Dosen mata kuliah Ekonomi Islam Pada Fakultas Ekonomi dan Bisnis Islam Universitas Islam Negeri Sumatera Utara (UIN-SU) Medan.

${ }^{2}$ Iskandar Putong, Ekonomi Mikro \& Makro, ( Jakarta: Ghalia Indonesia, 2003), h. 123.

${ }^{3}$ Sadono Sukirno, Mikro Ekonomi Teori Pengantar, ( Jakarta: Rajawali Pers, 2010), h. 231.

${ }^{4}$ Ibid, h. 232.

${ }^{5}$ Adiwarman A. Karim, Ekonomi Mikro Islami, ( Jakarta: PT. RajaGrafindo Persada, 2007), h. 173. 83.

${ }^{6}$ Afzalur Rahman, Doktrin Ekonomi Islam, ( Yogyakarta: Dana Bhakti Wakaf, 1995), h.

${ }^{7}$ Suherman Rosyidi, Pengantar Teori Ekonomi Pendekatan Kepada Teori Mikro \& Makro, ( Jakarta: PT. RajaGrafindo Persada, 2006), h. 507.

${ }^{8}$ Ibid, h. 452.

${ }^{9}$ Iskandar Putong, Ekonomi Mikro \& Makro, ( Jakarta: Ghalia Indonesia, 2003), h. 141.

${ }^{10}$ Pusat Pengkajian dan Pengembangan Ekonomi Islam, Ekonomi Islam, ( Jakarta: Rajawali Pers, 2009), h. 329-330.

${ }^{11}$ Hadis HR Muslim, Ahmad dan Abu Dawud.

${ }^{12}$ Azhari Akmal Tarigan, et al., Dasar-Dasar Ekonomi Islam, ( Bandung: Citapustaka Media, 2006), h. 196.

${ }^{13}$ Nur Chamid, Jejak Langkah Sejarah Pemikiran Ekonomi Islam, ( Yogyakarta: Pustaka Pelajar, 2010), h. 235. 1997), h. 257.

14 Yusuf Qardhawi, Norma Dan Etika Ekonomi Islam, ( Jakarta: Gema Onsani Press, 2006).

${ }^{15}$ Mustafa Edwin Nasution, et.al, Pengenalan Eksklusif Ekonomi Islam, ( Jakarta: Kencana,

\section{Daftar Pustaka}

Agung, I Gusti Ngurah, et. al., Teori Ekonomi Mikro Suatu Analisisi Produk Terapan. Jakarta: PT. RajaGrafindo Persada. 2008.

Chamid, Nur. Jejak Langkah Sejarah Pemikiran Ekonomi Islam. Yogyakarta: Pustaka Pelajar. 2010.

Karim, Adiwarman A. Ekonomi Mikro Islami. Jakarta: PT. RajaGrafindo Persada. 2007. 
22 | At-Tawassuth, Vol. III, No. 1, 2018: 1 - 22

Mannan, Muhammad Abdul. Teori Dan Praktek Ekonomi Islam. Yogyakarta: PT Dana Bhakti Wakaf. 1997.

Nasution, Mustafa Edwin, et. al, Pengenalan Eksklusif Ekonomi Islam. Jakarta: Kencana. 2006.

Pusat Pengkajian dan Pengembangan Ekonomi Islam. Ekonomi Islam. Jakarta: Rajawali Pers. 2009.

Putong, Iskandar. Ekonomi Mikro \& Makro, Jakarta: Ghalia Indonesia. 2003.

Qardhawi, Yusuf Qardhawi. Norma Dan Etika Ekonomi Islam. Jakarta: Gema Onsani Press. 1997.

Rahman, Afzalur. Doktrin Ekonomi Islam. Yogyakarta: Dana Bhakti Wakaf. 1995.

Rosyidi, Suherman. Pengantar Teori Ekonomi Pendekatan Kepada Teori Mikro \& Makro. Jakarta: PT. RajaGrafindo Persada. 2006.

Sukirno, Sadono. Mikro Ekonomi Teori Pengantar, Jakarta: Rajawali Pers. 2010.

Supriyitno, Eko. Ekonomi Islam Pendekatan Ekonomi Makro Islam dan Konvensional. Yogyakarta: Graha Ilmu. 2005.

Tarigan, Azhari Akmal, et. al., Dasar-dasar Ekonomi Islam. Bandung: Citapustaka Media. 2006. 